\title{
Bureaucratic Reform Strategy Employee Performance in the Secretariat of DPRD Kepulauan Riau Province
}

\author{
Fitri Kurnianingsih ${ }^{1},{ }^{2}$ Nazaki Nazaki, Oksep Adhayanto ${ }^{3}$ \\ ${ }^{1}$ Department Master Public Administration, Universitas Maritim Raja Ali Haji \\ ${ }^{2}$ Department Government Science, Universitas Maritim Raja Ali Haji \\ ${ }^{3}$ Department of Law, Universitas Maritim Raja Ali Haji \\ ${ }^{1}$ fitrikurnianingsih@umrah.ac.id, ${ }^{2}$ nazaki@umrah.ac.id , ${ }^{3}$ adhayantooksep@umrah.ac.id
}

\begin{tabular}{l}
\hline Keywords: \\
\hline Bureaucratic \\
Reform, \\
Performance, \\
Public Service, \\
DPRD, \\
Kepulauan Riau \\
\hline
\end{tabular}

\begin{abstract}
Bureaucratic reform is part of the organization's strategy to improve the quality of the organization's performance. The purpose of this research is to analyze the bureaucratic reform strategy in the Secretariat of the Regional House of Representatives (DPRD) of Kepulauan Riau Province on performance during the COVID-19 pandemic. The method used is descriptive qualitative, where the researcher makes observations according to the phenomena that exist within Kepulauan Riau Provincial DPRD Secretariat. Then the data analysis technique uses a logical model in accordance with the concept of performance which is part of bureaucratic reform. The results show that there is a weakening of the supporting factors in public services so that there is a weakening of organizational performance in facilities that are part of the supporting factors for Kepulauan Riau Provincial DPRD Secretariat due to the COVID-19 pandemic, besides that in the bureaucratic reform strategy, preparation and anticipation are needed in involving stakeholders if the involvement of other parties is considered necessary to encourage the improvement of the performance quality of the DPRD Secretariat of Kepulauan Riau Province.
\end{abstract}

Kata Kunci:

Reformasi

Abstrak

Birokrasi,

Reformasi birokrasi merupakan bagian dari startegi organisasi untuk meningkatkan kualitas kinerja agar organisasi tersebut. Tujuan penelitan untuk menganalisas strategi reformasi birokrasi di Seketariat Dewan Perwakilan Rakyat Daerah (DPRD) Provinsi Kepulauan Riau pada kinerja dalam masa pandemi COVID-19. Adapun metode yang digunukan mengunakan kualitatif deskriftif, dimana peneliti melakukan observasi sesuai dengan fenomena yang ada di lingkungan Seketariat DPRD Provinsi Kepulauan Riau. Kemudian teknik analisa data mengunakan model logika sesuai dengan konsep kinerja yang merupakan bagian dari reformasi birokrasi. Hasil 
menunjukan bahwa terjadinya pelemahan dari faktor pendukung pada pelayanan public sehingga terjadinya pelemahan kinerja organisasi pada fasilitas yang bagian dari factor pendukung Seketariat DPRD Provinsi Kepulauan Riau akibat kondisi pandemic COVID-19, selain itu dalam strategi reformasi birokrasi diperlukan persiapan serta antisipasi dalam melibatkan pemangku kepentingan jika keterlibatan pihak lainnya dianggap perlu untuk mendorong peningkatan kualitas kinerja Seketariat DPRD Provinsi Kepulauan Riau.

\section{Inroduction}

Bureaucratic reform is carried out in the context of realizing good governance, where bureaucratic reform is a strategic step to build a state civil apparatus so that it is more qualified in carrying out general duties of government, as an organizer of public services with the aim of meeting community needs in the form of goods or services in accordance with standards and the rules that have been set (Cope, 1997; Labolo \& Indrayani, 2017). The Indonesian bureaucracy has always been a public opinion that never gets boring, this is because until now the bureaucracy in Indonesia is still problematic and far from what was expected (Wihantoro et al, 2015; Iqbal, 2020). A bureaucracy that is not ideal is one of the problems in Indonesia.

Complaints about the low performance of public services and the lack of quality of apparatus resources seem never to end, and no effective solution can be found to overcome them (Hood \& Dixon, 2015). Starting from disgraceful practices such as collusion, corruption, and nepotism to a bad bureaucratic system that becomes obstacles in realizing a bureaucracy that is pro to the interests of the people at large, this has given birth to pathologies in the bureaucracy that have been passed down from generation to generation (Girling, 1997). Important changes became the starting point for the reform era in the political, legal, economic, and bureaucratic fields known as the first wave of reforms (Pedersen, 2012; Guérin, 2018).

The definition of public service according to Law number 25 of 2009 concerning Public Services, states that public services are activities or a series of activities in the context of fulfilling service needs in accordance with laws and regulations for every citizen and resident for goods, services, and/or administrative services provided by public service providers. Public service providers according to Law no. 27 of 2009 are any state administering institution, corporation, independent institution established under the law for public service activities, and other legal entities established solely for public service 
activities. In the law on public services, it is clearly stated that public service administering organizations are public service providers working within state administering institutions, corporations, independent institutions established under the law for public service activities, and other legal entities formed solely for activities. public service (Kopits, 2013; Mendel, 2013).

Therefore, public service implementers are officials, employees, officers, and everyone who works within the organizing organization in charge of carrying out an action or series of public service actions (Lipsky, 2010). Then to ensure that public services run well, the Public Service Law provides a reference in the form of service standards as a benchmark used as a guideline for service delivery and a reference for assessing service quality as an obligation and promise of administrators to the community in the context of quality, fast, easy, affordable service and measurable (Martin, 2013). These changes are based on the desire of the majority of the people to realize democratic governance and accelerate the realization of people's welfare based on basic values as stated in the Preamble to the 1945 Constitution as the goal of a state (Junaidi, 2018).

To support the performance of the DPRD in conducting supervision, the Secretariat of the Regional Representative Council of Kepulauan Riau Province provides services and facilitates all DPRD activities so that members of the Regional People's Representative Council of Kepulauan Riau Province can carry out their duties properly in realizing the development of Kepulauan Riau Province (Noviana, 2020). In order to provide services, the Secretariat of the Regional People's Representative Council of Kepulauan Riau Province is supported by adequate staff and infrastructure, in addition to policies from the Governor and the Leaders of the Regional People's Representative Council as references and guidelines in carrying out every activity, where these references and guidelines have been outlined by the Secretary Regional House of Representatives in the Organization's Vision and Mission.

The rolling bureaucratic reform demands changes in all structures of state life. In the implementation of the regional government, democracy and empowerment of local communities have become public discourses demanding the allocation and transfer of authority from the central government to regional governments to regulate and manage regions (Komendantova, 2018; Wolff, 2012). The formulation starts from policy, planning, to implementation and financing In the context of democracy, based on laws number 32 and 33 of 2004 concerning regional governance and on the financial balance 
between the central government and the prevailing regional governments, it has a very broad impact on the development of regional governance.

Bureaucratic reform will turn the government bureaucracy into a strong bureaucracy and become a world-class government, capable of providing excellent facilities and public services and free from KKN (Primanto et al, 2014). For this reason, bureaucratic reform must be carried out in a serious, consistent, institutionalized, gradual and sustainable manner. Thus, it is hoped that a bureaucracy will be able to support and accelerate the success of development in various fields (Chibber, 2002; Rigss, 2015) . Economic activity will increase and in the aggregate it will drive higher economic growth with the wider economic activity, there will be a larger basis for state revenue to finance the sustainability of bureaucratic reform and development in other broader fields (Wang, 2013).

Recipients of secretariat services have never been measured and surveyed, so there is no empirical data that shows how satisfied or dissatisfied the DPRD is with the services provided by the DPRD secretariat. On the one hand, the mandate of the Regulation of the Minister of State Apparatus Empowerment and Bureaucratic Reform of the Republic of Indonesia Number 16 of 2014 concerning Guidelines for the Survey of Public Satisfaction with the Implementation of Public Services requires that every government agency conduct a survey of public satisfaction with the delivery of public services as an evaluation material as well as improvements in the future. come. Based on the above, the importance of analysis on the bureaucratic reform strategy of employee performance at Kepulauan Riau Provincial DPRD secretariat during the Covid-19 pandemic.

\section{Metode}

The research method uses descriptive qualitative which emphasizes the process and meaning of social reality which is not rigorously tested or measured in terms of quantity or frequency (Newman et al, 1998). Data collection techniques by conducting a review of books, literature, notes, and various reports related to the problem to be solved and strengthening the results of observations in the field (Zed, 2004; Galvan \& Galvan, 2017). In general, this type of qualitative descriptive research is often used to analyze social events, penomena or circumstances (Dey, 2003; Merriam, 2002). 


\section{Result And Discussion}

Changes in the internal system include aspects of internal systems and procedures that are simple and fast to enable services to run effectively and efficiently. Establishing service standards that enable people to obtain certainty for the services they want. Changes in a work culture that are oriented towards a quality culture with a focus on services provided to members of the DPRD Kepulauan Riau Province who is served by establishing service ethics to improve support for facilities and infrastructure, including the use of information technology documentation systems for easy access for the public to open communication services with the community various media providing information for the community and other service systems.

Changes in aspects of human resources include, among other things, leadership that is more oriented towards individual competency services which is more oriented towards professional service where each individual has patience, friendliness, proactively masters the field of duty well, has high discipline responsibility, respects the community served, productive, employee development system that is oriented towards increasing competence for servants, granting authority to spearhead officers to make decisions in order to solve problems that arise when services are implemented, a reward and punishment system that is supported by a performance appraisal system that reflects the real performance of the system. Supervision of superiors to subordinates in the framework of the internal control system. There are four components in the reform strategy, namely

\section{Good Performance and Effective Service}

Good performance is a performance that follows procedures or procedures according to established standards. However, in this performance, several criteria must be order to increase productivity so that what is expected can run as desired (Rotberg, 2014). While the service is said to be effective if the apparatus is successful in carrying out its duties. In other words, the success of the government's task in national development depends a lot on the work and abilities of civil servants (Asgarkhani, 2005). Good and effective governance is seen from a performance, at this time performance during the COVID-19 pandemic has greatly changed the pattern of public services. One of them is the performance of the staff of the Kepulauan Riau Provincial DPRD secretariat. Based on the results of observations of the findings of secondary data, researchers show that the majority of employees in providing public services to several 
factions of members of Kepulauan Riau Province DPRD are not optimal, this is because in preventing the spread of COVID-19 so as to guide some existing employees to work at home and not present in the form of services. which should be their duty to work. Technological services also cannot be maximized due to the unstable position of the archipelago with access to technology and information.

Furthermore, in the context of cleanliness and effectiveness of performance carried out by the secretariat staff Kepulauan Riau Provincial DPRD in accordance with existing regulations. Clean performance is shown by the absence of issues or news that services in the performance of Kepulauan Riau Provincial DPRD secretariat employees are still in the positive category, which is better by promoting performance ethics to maintain bureaucratic reform to be better in public services and avoid maladministration in the executive bureaucracy.

\section{Information Systems Open to the Public}

The system is a network of procedures that are interconnected, gathered together to carry out an activity or to complete a certain goal, while information is data that is processed into a form that is more useful for those who receive it (McNurlin et al, 2005). An important role in realizing open state administration is the public's right to obtain information in accordance with statutory regulations. The right to information is very important because the more open the state is to be monitored by the public, the more accountable the state administration becomes. The right of everyone to obtain information is also relevant for improving the quality of community involvement in the public decision-making process. Public participation or involvement does not mean much without guaranteeing the openness of public information. Based on the observations of researchers, the information system on employee performance in strengthening the bureaucracy of Kepulauan Riau Provincial DPRD secretariat shows that the use of information systems in the implementation of the proper rights of the public is inadequate and far below the standard of information systems.

For example, the absence of technology in the form of mass media such as the website for the secretariat of Kepulauan Riau Provincial DPRD secretariat, both in the form of Videotron, does not yet exist to provide information on the performance activities of Kepulauan Riau Provincial DPRD secretariat. The service information system from the secretariat to members of the DPRD Kepulauan Riau Province still uses the right to 
questionnaire in the form of a form to assess the performance of the staff of Kepulauan Riau Provincial DPRD secretariat. But the researchers have not found that the information system has not been significantly budgeted for by means of Kepulauan Riau Provincial DPRD secretariat facility.

However, in the context of bureaucratic reform, it is necessary to have competent human resources to be responsible for managing the information system both in terms of performance reports and informal conditions carried out by the DPRD Secretariat of Kepulauan Riau Province. The dimensions of bureaucratic reform should better prioritize public digitization-based information systems. It is intended that the people who visit Kepulauan Riau Provincial DPRD secretariat know what activities have been carried out both in the long and short term.

\section{Competent Human Resources}

Human Resource Competence is the ability and characteristics possessed by a person in the form of knowledge, skills, and behavioral attitudes needed in carrying out his duties in his work environment (Benbrahim et al, 2017). Human resources are the most important and most decisive factor in every organization. It is the determinant of the progress or progress of an organization. Human resources are human capital and intellectual capital that will determine the effectiveness of other resources owned by an organization such as capital/funds, equipment, organizational technology, structure, and others. As good as any system that has been prepared or equipped and whatever the facilities and infrastructure are available in the organization, without being supported by the existence of human resources who have.

Currently, the human resources at the DPRD Secretariat of Kepulauan Riau Province are met in quantity according to the needs of the environment in carrying out their duties, but in quality, there is a need for improvement in the form of socialization and technical guidance for the success of bureaucratic reform, among others through achieving targets with key performance indicators) well fulfilled. If the goals above are achieved gradually, it is expected that quality governance will result. The better the governance quality, the better the development outcomes (development outcomes). So it is necessary for the future importance of developing human resources through competency-based public services as an effort to strengthen performance capacity. 


\section{Actively Participating and Serving}

Participatory, services can encourage community participation in the implementation of public services by taking into account the aspirations, needs and expectations of the community, Participation in serving is basically a form of active involvement and participation of all parties in the entire process of institutional activities (Swapan, 2016; Mahadiansar et al, 2021). Participatory is a collaboration between two or more people, the role is not only limited in terms of participating physically but involvement which allows carrying out an assessment of the problems and potentials contained in their own environment, then determining the activities they need. Participation in the performance of Kepulauan Riau Provincial DPRD secretariat is still minimal and will serve optimally, for example, there are not many community activities visiting to convey aspirations to employees both formally and informally.

Based on the results of the observations that the researcher found, there was no service campaign with the slogan of serving well. This makes the public's ignorance of the performance of Kepulauan Riau Provincial DPRD secretariat not having a very important role, so it is necessary to have participatory bureaucratic reform in serving based on initiative empowerment of performance. Initiatives, in the sense that they can show breakthrough participation, serve by maintaining their role as professional employees of Kepulauan Riau Provincial DPRD secretariat. This community involvement is the involvement that leads to the growth of their abilities to be more empowered in facing life's challenges without having to depend on others. When the role of society is strong, the role of outsiders is reduced. Therefore, participatory public services are needed, even participatory public services can be the main force for improvement in public services.

\section{Conclusion}

Changes in the strategic pasa of bureaucratic reform that must be carried out at the DPRD Secretariat of Kepulauan Riau Province as mentioned above require the fulfillment of the following principles:

1. A clear plan in employee performance, bureaucratic reform must have a clear vision with the mission, goals and objectives leading to the achievement of the vision, so that changes can be taken operationally in a measurable order of priority, targets that must be achieved can be achieved. measured with certainty the time to reach which 
shows step by step change will be achieved.

2. Reform must be carried out with a high commitment from the top leadership, which is shown through the provision of performance units and staff of Kepulauan Riau Provincial DPRD Secretariat having the capacity to handle services well.

3. All elements in the organization of government agencies must have joint efforts that go hand in hand to bring about a change, synergy is needed in order to see the relationship and balance of all efforts made by work units and individuals, all elements in the organization have an important role in realizing change efforts. therefore, if these elements work partially or do not function as they should, the balance of efforts to achieve change goals will be disturbed.

4. The reform process requires continuous communication from both the leadership to their subordinates in the form of support, regular meetings, discussions, formal and informal or the form of communication via internet media, communication not only encourages synergy but will also encourage the exchange of knowledge that makes the possibility of innovations in this condition is very necessary in the process of bureaucratic reform.

5. All of the above principles must be implemented consistently, it is very important to be consistently implemented in an effort to create internalization for every individual, when each individual realizes the importance of change, efforts to make changes for the better will become a culture that will accelerate the process of bureaucratic reform.

\section{Daftar Pustaka}

Asgarkhani, M. (2005). The effectiveness of e-service in local government: a case study. The electronic journal of e-government, 3(4), 157-166.

Benbrahim, C. F., Sefiani, N., Meddaoui, A., \& Reklaoui, K. (2017). Assessment of human resource competence and performance indicator. International Journal of Process Management and Benchmarking, 7(1), 20-37.

Chibber, V. (2002). Bureaucratic rationality and the developmental state. American journal of sociology, 107(4), 951-989.

Cope, G. H. (1997). Bureaucratic reform and issues of political responsiveness. Journal of Public Administration Research and Theory, 7(3), 461-471.

Dey, I. (2003). Qualitative data analysis: A user friendly guide for social scientists. Routledge. 
Galvan, J. L., \& Galvan, M. C. (2017). Writing literature reviews: A guide for students of the social and behavioral sciences.

Girling, J. (1997). Corruption, capitalism and democracy (Vol. 4). Psychology Press.

Guérin, N. (2018). One wave of reforms, many outputs: the diffusion of European asylum policies beyond Europe. Journal of European Public Policy, 25(7), 1068-1087.

Hood, C., \& Dixon, R. (2015). What we have to show for 30 years of new public management: Higher costs, more complaints. Governance, 28(3), 265-267.

Iqbal, M. (2020). Bureaucratic Reform in Indonesia: Best and Bad Practice Perspective. Asian Review, 33(2), 34-54.

Junaidi, M., \& Tatas, T. (2018). The Relevance of Legal State Idea in Ensuring the Realization of the People's Welfare. In 1st International Conference on Intellectuals' Global Responsibility (ICIGR 2017). Atlantis Press.

Komendantova, N., Riegler, M., \& Neumueller, S. (2018). Of transitions and models: Community engagement, democracy, and empowerment in the Austrian energy transition. Energy Research \& Social Science, 39, 141-151.

Kopits, G. (2013). Restoring public debt sustainability: the role of independent fiscal institutions. OUP Oxford.

Labolo, M., \& Indrayani, E. (2017). Bureaucratic reform and the challenge of good governance implementation in Indonesia. Journal of Asian Review Public Affair and Policy, 2(4), 25-47.

Lipsky, M. (2010). Street-level bureaucracy: Dilemmas of the individual in public service. Russell Sage Foundation.

Mahadiansar, M., \& Ramadhan, P. (2021). Strategi Partisipasif Pembangunan Sosial; Studi Di Pulau Penyengat Kota Tanjungpinang. Civitas Consecratio: Journal of Community Service and Empowerment, 1(1), 43-5.

Martin, P. Y. (2013). Rape work: Victims, gender, and emotions in organization and community context. Routledge.

McNurlin, B. C., \& Sprague, R. H. (2005). Information systems management in practice. Prentice-Hall, Inc.

Mendel, T. (2013). Public service broadcasting: A comparative legal survey. Unesco.

Merriam, S. B. (2002). Introduction to qualitative research. Qualitative research in practice: Examples for discussion and analysis, 1(1), 1-17. 
Newman, I., Benz, C. R., \& Ridenour, C. S. (1998). Qualitative-quantitative research methodology: Exploring the interactive continuum. SIU Press.

Noviana, N. (2020). Sistem Informasi Koordinasi Kelengkapan Dewan pada Dewan Perwakilan Perwakilan Rakyat Daerah Provinsi Kepulauan Riau. Jurnal JTIK (Jurnal Teknologi Informasi dan Komunikasi), 4(1), 1-7.

Pedersen, R. H. (2012). Decoupled implementation of new-wave land reforms: decentralisation and local governance of land in Tanzania. Journal of Development Studies, 48(2), 268-281.

Primanto, A., Suwitri, S., \& Warsono, H. (2014). Bureaucratic Reform: A Way to Eliminate Corruption, Collusion, and Nepotism Practices in Indonesia. International Journal of Economics, Commerce and Management, 2(10).

Riggs, F. W. (2015). Bureaucrats and Political Development: A Paradoxical View (pp. 120-167). Princeton University Press.

Rotberg, R. I. (2014). Good governance means performance and results. Governance, 27(3), 511-518.

Swapan, M. S. H. (2016). Who participates and who doesn't? Adapting community participation model for developing countries. Cities, 53, 70-77.

Wang, A. L. (2013). The search for sustainable legitimacy: environmental law and bureaucracy in China. Harv. Envtl. L. Rev., 37, 365.

Wihantoro, Y., Lowe, A., Cooper, S., \& Manochin, M. (2015). Bureaucratic reform in post-Asian crisis Indonesia: The directorate general of tax. Critical Perspectives on Accounting, 31, 44-63.

Wolff, J. (2012). Democracy promotion, empowerment, and self-determination: conflicting objectives in US and German policies towards Bolivia. Democratization, 19(3), 415-437.

Zed, M. (2004). Metode penelitian kepustakaan. Yayasan Obor Indonesia. 